\title{
CHANGES DURING STORING AND ASTRINGENCY REMOVAL OF PERSIMMON FRUIT (DIOSPYROS KAKI L.)
}

\author{
J. HRIBAR, M. ZAVRTANIK, M. SIMČIČ, and R. VIDRIH \\ Dep. of Food Science and Technology, University of Ljubljana, Biotechnical Faculty, \\ Jamnikarjeva 101, 1000 Ljubljana. Slovenia
}

(Received: 29 June 1999; accepted: 19 December 1999)

\begin{abstract}
Physiological changes during ripening, storing and astringency removal of persimmon fruits were traced. The fruits were stored under normal (NA), controlled (CA) and vacuum atmospheres (VA). The fruits were stored for 100 days and analysed for firmness, acetaldehyde and ethanol content and soluble tannins, both before and after storing. The same analyses were done during the deastringency treatment carried out with a high $\mathrm{CO}_{2}$ concentration $(99.99 \%)$ for $20 \mathrm{~h}$ at $20^{\circ} \mathrm{C}$. The persimmon fruits stored under NA, CA, VA or treated with high $\mathrm{CO}_{2}$ for $20 \mathrm{~h}$ accumulated acetaldehyde and ethanol in the fruit tissue. CA conditions caused the highest acetaldehyde accumulation; vacuum conditions the lowest. Ethanol content increased 20 fold during storage; the highest accumulation was observed in vacuum stored fruit followed by $\mathrm{CA}$ $\left(3 \% \mathrm{CO}_{2}-2 \% \mathrm{O}_{2}\right.$ and $\left.0.5 \% \mathrm{CO}_{2}-2 \% \mathrm{O}_{2}\right)$ conditions. Astringency removal treatment caused an immediate increase of acetaldehyde and ethanol, nearly to the same extent as in conventionally ripened or stored fruit. The amount of soluble tannins, the main cause of an astringent taste, decreased during storage, and it did much faster during deastringency removal at the same level. The sensory evaluation test revealed that fruit treated with high $\mathrm{CO}_{2}$ was preferred to conventionally ripened fruit.
\end{abstract}

Keywords: acetaldehyde, astringency removal, ethanol, persimmon, storing, tannins

Persimmon fruit (Diospyros kaki L.) originates from Southeast Asia, but is now cultivated in other regions with suitable climatic conditions. Its popularity is most prominent in Japan, where it ranks fifth in fresh fruit production with non-astringent cultivars. Persimmon has at least 1000 cultivars, which are classified into the following four groups:

- Non-astringent and pollination constant (PCNA) cultivars have dark tannin spots.

- Non-astringent and pollination variant (PVNA) cultivars have dark tannin spots and may become astringent when seedless.

- Astringent and pollination constant (PCA) cultivars have no dark tannin spots.

- Astringent and pollination variant (PVA) cultivars may become non astringent when pollinated (HULME, 1971). 
Non-astringent cultivars are consumed as fresh fruits, but astringent cultivars are edible only after the removal of astringency or as a dried fruit (ITOO, 1971). Nonastringent cultivars contain up to $1 \%$ soluble tannins, which start to decrease before harvest and ripening. The astringent cultivars contain many more soluble tannins than non-astringent cultivars at their maximum value in July, then they decrease gradually during on-tree maturation and reach $2 \%$ at harvest time (ITOO, 1971).

The astringent type persimmon fruit is not edible at harvest due to the presence of soluble tannins that cause an astringent taste in the mouth (KAYS, 1991). Astringent taste is a consequence of the coagulation of tannins with salivary proteins that results in insoluble rough complexes. Soluble tannins are made up from catechin, catechin-3galate, galocatechin and galocatechin-3-galate (MATSUO \& ITOO, 1978). Tannins are also found in other plant parts; ehtyl acetate extract from persimmon leaves contains catechin and galocatechin (SEONG, 1986). The fruit becomes edible during postharvest ripening, when soluble tannins polymerise and become insoluble (MATSUO \& ITOO, 1982). Normal postharvest ripening during shelf life includes natural tannin polymerisation, but also fruit softening; edible naturally non-astringent fruits are very soft and thus susceptible to mechanical and microbiological spoilage.

On-tree fruit ripening is associated with the accumulation of acetaldehyde (AA) and ethanol (ET) in postclimacteric 'Bartlett' pears (KE \& VAN GORSEL, 1990) and cherries (VIDRIH et al., 1998). A much higher accumulation of acetaldehyde and ethanol occurs during anaerobic metabolism at very low $\mathrm{O}_{2}$ and/or high $\mathrm{CO}_{2}$ concentration $(>80 \%)$ in persimmons (PESIS et al., 1988) or cherries (VIDRIH et al., 1998). Low $\mathrm{O}_{2}$ stressed 'Bartlett' pears increase the synthesis of acetaldehyde and ethanol (KE \& VAN GORSEL, 1990).

Besides natural deastringency that occur during normal ripening of persimmon fruit, the absence of $\mathrm{O}_{2}$ (balance $\mathrm{N}_{2}$ ) or $\mathrm{CO}_{2}$ content above $80 \%$ provokes the astringency removal in persimmon fruit (PESIS \& BEN-ARIE, 1984). $\mathrm{CO}_{2}$ enriched atmospheres provoke the accumulation of acetaldehyde and ethanol in Bartlett pears when $\mathrm{CO}_{2}$ exceeds 50\% (KE \& VAN GORSEL, 1990). PESIS and BEN-ARIE (1984), PESIS and co-workers (1988), demonstrated a positive correlation between the atmospheric $\mathrm{CO}_{2}$ content and the accumulation of acetaldehyde in fruit tissue. The ethanol accumulation did not follow the pattern of acetaldehyde; the final ethanol concentration was nearly the same, independent of $\mathrm{CO}_{2}$ concentration. PESIS and BEN-ARIE (1984) suggested that $\mathrm{CO}_{2}$ depresses the conversion of acetaldehyde to ethanol. Higher acetaldehyde content enables the most effective astringency removal. A higher $\mathrm{CO}_{2}$ concentration always produces more acetaldehyde and makes astringency removal faster. Temperature plays an important role in anaerobic metabolism. Higher temperature makes commodities more susceptible to anaerobic metabolism; more acetaldehyde and ethanol accumulate at higher temperatures. 
The storing of fruit in acetaldehyde vapours causes the accumulation of both acetaldehyde and ethanol to the same extent as in fruit stored in $\mathrm{N}_{2}$ or in $\mathrm{CO}_{2}$. On the other hand, ethanol vapours provoke the accumulation of both acetaldehyde and ethanol in fruit tissue. Fruits are capable of transforming the exogenous acetaldehyde into ethanol and vice versa, as demonstrated by VIDRIH and co-workers (1999).

Acetaldehyde is much more toxic to the fruit cell, compared to ethanol. To prevent injuries, the cell transforms toxic acetaldehyde into the less toxic ethanol that is the final product of anaerobic respiration. Many injuries are known to be associated with acetaldehyde accumulation in pome fruits (WILKINSON \& FIDLER, 1973); $\mathrm{CO}_{2}$ injuries in the apple (SMAGULA \& BRAMLAGE, 1977). When anaerobic conditions last too long, fruit damage may result such as blossom-end browning, skin browning or internal breakdown.

Naturally non-astringent cultivars contain ten times more acetaldehyde than astringent cultivars (NAKAMURA, 1973). Acetaldehyde and ethanol contents were much higher in PCNA or PVNA cultivars than in PVA or PCA cultivars at harvest (CHOI, 1977, CHOI \& SOHN, 1977). On the other hand, PVA and PCA cultivars have much higher amount of soluble tannins (SUGIURA et al., 1979) and thus are astringent. Acetaldehyde and ethanol concentration in seeds usually follows that in mesocarp; some authors propose that seeds are the primary source of acetaldehyde and ethanol (SUGIURA et al., 1979). Acetaldehyde is known to play a decisive role in the process of natural or high $\mathrm{CO}_{2}$ induced de-astringency (MATSUO \& ITOO, 1977, SUGIURA et al., 1979, Sugiura \& TOMANA, 1983, MATSuO \& ITOO, 1981a, b, MATSuO \& ITOO, 1982).

Kaki tannin polymerises by reacting with acetaldehyde in vitro, as demonstrated by MATSUO and ITOO (1982). pH plays an important role; a low $\mathrm{pH}$ (below 3.5) causes rapid tannin gelation; the minimum rate of gelation was observed at $\mathrm{pH} 4-5$; gelation was again stimulated in the $6-8 \mathrm{pH}$ range (MATSUO \& ITOO, 1982). In vitro tannin polymerisation within persimmon fruit tissue was demonstrated to depend mostly on acetaldehyde concentration.

The aim of this work was to study the post harvest behaviour of persimmon cultivars grown in Slovenia. The emphasis was given to the processes accompanying the removal of astringent taste, either during the storage of persimmon fruit or during its exposure to high $\mathrm{CO}_{2}$ treatment. 


\section{Materials and methods}

\subsection{Raw material}

Six cultivars (Fuji, Hachyia, Lycopersicon, Kaki Tipo, Kurokuma, and Thiene) of persimmon fruit (Diospyros kaki, L.) were harvested at the end of October 1997 in commercial orchard. According to BELLINI (1982) cultivars Fuji, Hachyia and Lycopersicon belong to astringent pollination constant group (PCA), while Kaki Tipo, Kurokuma and Thiene belong to astringent pollination variant (PVA) group. At harvest all the fruits were still astringent, firm, similar in size and colour and free of diseases.

\subsection{Storage conditions}

Each cultivar ( $40 \mathrm{~kg}$ ) was stored in a normal atmosphere (NA) at $0{ }^{\circ} \mathrm{C}$ in air at 90-95\% relative humidity, vacuum atmosphere $(70 \mathrm{~mm} \mathrm{Hg})$ (VA) or under two different controlled atmosphere $(\mathrm{CA})$ conditions. Controlled atmosphere storage was conducted in a plastic container $\left(1 \mathrm{~m}^{3}\right)$; fruits were sealed in a plastic container $\left(1 \mathrm{~m}^{3}\right)$ and a desirable atmosphere was established by streaming the $\mathrm{O}_{2}$ out by means of $\mathrm{N}_{2}$. The desired $\mathrm{CO}_{2}$ level was achieved by means of fruit respiration. Two different CA conditions $\left(3 \% \mathrm{CO}_{2}-2 \% \mathrm{O}_{2}\right)$ and $\left(0.5 \% \mathrm{CO}_{2}-2 \% \mathrm{O}_{2}\right)$ were performed; CA conditions were monitored and controlled by a computer (Fruit Controll, Italy).

The vacuum atmosphere (VA) was established in aluminum jars (20 1) by the constant working of a vacuum pump. The fruit was put into the jars, and the desired pressure was maintained at $70 \mathrm{~mm} \mathrm{Hg}$ by means of controlling the air flow into each jar. The air was continually passed through the water in order to maintain the highest possible relative humidity content in the jars.

The fruits were stored for 100 days.

\subsection{Method for astringency removal}

Concentration of soluble tannins decrease slowly during normal ripening of persimmon fruit in air at ambient temperature, but is known to decrease more rapidly in a so called deastringency treatment. In the deastringency treatment, the fruits $(30 \mathrm{~kg}$ of each cultivar) were transferred to $20{ }^{\circ} \mathrm{C}$ on the day of harvest. They were sealed in a plastic container $\left(1 \mathrm{~m}^{3}\right)$; a desirable atmosphere $\left(99.99 \% \mathrm{CO}_{2}\right)$ was established by streaming the $\mathrm{O}_{2}$ out with $\mathrm{CO}_{2}$. The fruits were treated for $20 \mathrm{~h}$ at $20^{\circ} \mathrm{C}$, then transferred to air and maintained at $20{ }^{\circ} \mathrm{C}$ for an additional $72 \mathrm{~h}$. 


\subsection{Determination of firmness}

Fruit firmness was measured with a penetrometer (Chatillon, USA) equipped with an $11 \mathrm{~mm}$ plunger on the peeled fruit; for each treatment 10 fruits were assayed, and four measurements were made on each fruit.

\subsection{Determination of acetaldehyde and ethanol}

Acetaldehyde and ethanol contents were measured according to the method described by BONGHI and co-workers (1999). Fruit tissue was frozen under liquid $\mathrm{N}_{2}$ and kept at $-20{ }^{\circ} \mathrm{C}$ until further use. Ten $\mathrm{g}$ of tissue was homogenised under liquid $\mathrm{N}_{2}$ and mixed with $10 \mathrm{~g}$ of water. The homogenate was then centrifuged; $5 \mathrm{ml}$ of the supernatant was pipetted into a vial, tightly closed with a septum and incubated at $55{ }^{\circ} \mathrm{C}$. One $\mathrm{ml}$ of head space gas was taken after half an hour and injected into GC. Five different concentrations of acetaldehyde and ethanol were analysed in the same way in order to establish a calibration curve. The acetaldehyde and ethanol were analysed on a GC (Hewlett Packard 5890 II) equipped with an HP-FFAP $(25 \mathrm{~m} \times 0.2 \mathrm{~mm} \times 0.3 \mu \mathrm{m})$ column and FID detector. The temperature programming was isothermal at $40{ }^{\circ} \mathrm{C}$.

\subsection{Determination of soluble tannin}

Folin-Ciocalteau method was used with gallic acid standards at 6 different concentrations ranging from 20 to $500 \mathrm{mg} \mathrm{l}^{-1}$. Ten $\mathrm{g}$ of fruit was homogenized with 10 $\mathrm{g}$ of water by means of Ultraturax; suspension was then filtered through four layers of cheese cloth and centrifuged $(2000 \times \mathrm{g})$. Supernatant $(0.1 \mathrm{ml})$ was mixed with $1.9 \mathrm{ml}$ of water and $10 \mathrm{ml}$ of Folin-Ciocelteau (1:3) and allowed to stand for $8 \mathrm{~min}$; finally $8 \mathrm{ml}$ of $\mathrm{Na}_{2} \mathrm{CO}_{3}(20 \%)$ was added. Absorbance at $765 \mathrm{~nm}$ was recorded after $2 \mathrm{~h}$.

\subsection{Sensory evaluation}

A comparative sensory evaluation by 15 trained panellists was performed. The panellists compared the fruits of the cultivar Fuji exposed to the astringency removal treatment (high $\mathrm{CO}_{2}$, see 1.3) to naturally ripened fruits of the same cultivar. Naturally ripened fruits were stored in air at $20{ }^{\circ} \mathrm{C}$ until an edible taste (not astringent) was achieved.

\subsection{Determination of the activity of alcohol dehydrogenase}

Alcohol dehydrogenase activity was measured according to the method described by BONGHI and co-workers (1999).

Five $\mathrm{g}$ of the mesocarp was homogenized in $10 \mathrm{ml}$ of extraction buffer consisting of $100 \mathrm{mM} \mathrm{KK_{2 }} \mathrm{PO}_{4} \mathrm{pH} 7.5,2 \mathrm{mM} \mathrm{MgCl} 2,1 \mathrm{mM} \beta$-mercaptoethanol, 
$0.2 \%$ Triton X-100, 1\% PVPP with ultraturax. The homogenate was filtered through four layers of cheese cloth and centrifuged at $18000 \times \mathrm{g}$ for $20 \mathrm{~min}$.

The reaction mixture consisted of $0.68 \mathrm{ml}$ of glicine buffer $\mathrm{pH} 9.0,0.07 \mathrm{ml} \mathrm{NAD}^{+}$ $11.4 \mathrm{mM}, 0.15 \mathrm{ml}$ of ethanol $2 \mathrm{M}$ and $0.1 \mathrm{ml}$ of enzyme extract.

The reduction of $\mathrm{NAD}^{+}$was measured by recording the increase in absorbancy at $340 \mathrm{~nm}$

\subsection{Evaluation of data}

The data (from three determinations of each treatment) were analysed by the method of the least squares using the GLM procedure (SAS, 1990). The statistical model for parameters included the effects of M, C and D (Model 1).

$$
y_{\mathrm{ijkl}}=\mu+\mathrm{M}_{\mathrm{j}}+\mathrm{C}_{\mathrm{j}}+\mathrm{D}_{\mathrm{k}}+\mathrm{e}_{\mathrm{ijkl}}
$$

where $y_{\mathrm{ijkl}}$ the observation $\mathrm{ijkl}, \mu$ : general mean, $\mathrm{M}$ : effect of methode $\mathrm{i}$ ( $\mathrm{i}=1 \mathrm{NA}$, $\mathrm{i}=2 \mathrm{CA} 0.5 \% \mathrm{CO}_{2}-2 \% \mathrm{O}_{2}, \mathrm{I}=33 \% \mathrm{CO}_{2}-2 \% \mathrm{O}_{2}, \mathrm{i}=4$ vacuum), $\mathrm{C}_{\mathrm{j}}=$ effect of cultivar $\mathrm{j}$ $(\mathrm{j}=1,2,3,4,5,6), \mathrm{D}_{\mathrm{k}}$ : effect of determination $\mathrm{k}(\mathrm{k}=1,2,3)$, and $\mathrm{e}_{\mathrm{ijk}}=$ residual random term with variance $\sigma_{\mathrm{e}}^{2}$.

In addition, in the analysis of astringency removal, the statistical model 2 included the effect of T, C and D:

$$
y_{\mathrm{ijkl}}=\mu+\mathrm{T}_{\mathrm{j}}+\mathrm{C}_{\mathrm{j}}+\mathrm{D}_{\mathrm{k}}+\mathrm{e}_{\mathrm{ijkl}}
$$

where $\mathrm{T}_{\mathrm{j}}=$ effect of time $\mathrm{i}$ after treatment ( $\mathrm{i}=1$ beginning, $\mathrm{i}=220 \mathrm{~h}, \mathrm{i}=392 \mathrm{~h}$ ), all the other parameters have the same meaning as above.

Least square means for experimental groups were obtained using the LSM procedure (SAS, 1990) and were compared at the 5\% probability level.

\section{Results and discussion}

\subsection{Firmness}

The most rapid decrease of firmness occurred in the fruit stored in NA. Both CA storage conditions had a beneficial effect on keeping fruit firmness, as compared to the NA system (Table 1). The vacuum had a more pronounced effect on fruit firmness retention; vacuum stored fruit had a four fold higher firmness compared to CA conditions, probably due to the low $\mathrm{O}_{2}$ concentration within the fruit tissue. Persimmon fruit produces a relatively low amount of ethylene, which is permanently removed under vacuum conditions and cannot influence ripening. The $\mathrm{CO}_{2}$ induced deastringency provoked a higher decrease of fruit firmness compared to the $\mathrm{N}_{2}$ induced deastringency, as also observed by PESIS and BEN-ARIE (1984). 
Table 1

Fruit firmness (N) of persimmon, before and after storing the fruit under different conditions

\begin{tabular}{|c|c|c|c|c|c|c|c|c|c|}
\hline \multirow{2}{*}{ Cultivar } & \multirow{2}{*}{ At harvest } & \multicolumn{7}{|c|}{ After storage } & \multirow{2}{*}{ F value } \\
\hline & & 1 & & 2 & & 3 & & 4 & \\
\hline Fuji & $71.6 \pm 4.0$ & $<15$ & 21.6 & \pm 2.2 & & - & & - & \\
\hline Hachyia & $76.5 \pm 5.9$ & $<15$ & 30.4 & \pm 4.4 & 31.4 & \pm 3.2 & & - & 0.11 \\
\hline Kaki Tipo & $102.0 \pm 9.7$ & $<15$ & $15.7^{4}$ & \pm 1.5 & $17.7^{4}$ & \pm 0.9 & 67.7 & \pm 5.7 & $221.74 * * *$ \\
\hline Lycopersicon & $100.0 \pm 9.5$ & $<15$ & 30.4 & \pm 4.0 & 27.5 & \pm 1.9 & & - & 1.22 \\
\hline Thiene & $102.0 \pm 4.8$ & $<15$ & $30.4^{3}$ & \pm 4.7 & 21.6 & \pm 2.0 & & - & $8.68 * * *$ \\
\hline
\end{tabular}

-: no data

$* * * \mathrm{P} \leq 0.001 ; * * \mathrm{P} \leq 0.01 ; * \mathrm{P} \leq 0.05$

Values represent the mean of ten fruits \pm S.E.

1: $\mathrm{NA} ; 2$ : $\mathrm{CA} 0.5 \% \mathrm{CO}_{2}-2 \% \mathrm{O}_{2} ; 3: \mathrm{CA} 3 \% \mathrm{CO}_{2}-2 \% \mathrm{O}_{2} ; 4$ : VACUUM $70 \mathrm{~mm} \mathrm{Hg}$

The figures above averages show that they are significantly different from the treatment indicated by the figure

\subsection{Tannin}

The fresh parthenocarpic fruits contained from 1.6 to $4.1 \%$ soluble tannin at harvest (Table 2). A tannin concentration above $0.1 \%$ conferred an astringent taste; such fruits are not edible (SEONG, 1986). On the other hand, the fruit with seeds (at least 2) were much lower in tannin content $(0.03 \%$, Table 2$)$, but still slightly astringent at the part most distant from the seeds. Seeds are involved in acetaldehyde production; the mesocarp located around the seed is not astringent. The fruit from all the storage conditions had a soluble tannin concentration below $50 \mathrm{mg} / 100 \mathrm{~g}$ after storing. CA conditions conferred a lower soluble tannins concentration because of partially anaerobic conditions, or a higher $\mathrm{CO}_{2}$ concentration. Significant differences in tannin content were found among different storage conditions, vacuum stored fruit had the lowest tannin content, followed by $\mathrm{CA} 3 \% \mathrm{CO}_{2}-2 \% \mathrm{O}_{2}, \mathrm{CA} 0.5 \% \mathrm{CO}_{2}-2 \% \mathrm{O}_{2}$ and $\mathrm{NA}$.

\subsection{Content of acetaldehyde and ethanol}

Acetaldehyde increases during the storage time (Table 3). Persimmon ripening involves acetaldehyde accumulation; this phenomenon is also known in other fruits. Significant differences in acetaldehyde content among the treatments were found except for the cultivar Lycopersicon. Aacetaldehyde concentration was lower in vacuum treatments because of the permanent removal of acetaldehyde due to its high volatility. PESIS and co-workers (1988) found the highest concentration of acetaldehyde in persimmon fruit enclosed in PE bags with $\mathrm{CO}_{2}$ for $48 \mathrm{~h}$, followed by vacuum treated fruits and $\mathrm{N}_{2}$ treated fruits. 
Table 2

Concentration of tannin in persimmon $(\mathrm{mg} / 100 \mathrm{~g}$ f.w.) before and after storing the fruit under different storage conditions for 100 days

\begin{tabular}{|c|c|c|c|c|c|c|c|c|c|}
\hline \multirow{3}{*}{ Cultivar } & \multicolumn{2}{|c|}{ At harvest } & \multicolumn{6}{|c|}{ After storage } & \multirow[b]{2}{*}{ F value } \\
\hline & & & 1 & & & 2 & 3 & 4 & \\
\hline & Seedless & With seeds & & & Seedless & & Seedless & & \\
\hline Fuji & $4100 \pm 740$ & - & $40.0^{2,4}$ & \pm 7 & 7.0 & $13.3^{3} \pm 1.7$ & $33.3^{4} \pm 2.5$ & $13.3 \pm$ & $1.5 \quad 39.85^{* * *}$ \\
\hline Hachyia & $3400 \pm 257$ & - & & - & & - & - & - & \\
\hline Kaki Tipo & $2150 \pm 330$ & $17.0 \pm 2.0$ & $33.3^{2,3,4}$ & \pm 4 & 4.6 & $20.0^{4} \pm 3.5$ & $20.0^{4} \pm 2.6$ & $6.7 \pm$ & $0.6 \quad 34.39 * * *$ \\
\hline Kurokuma & $3250 \pm 335$ & - & $120.0^{2,3}$ & \pm 9 & 9.2 & $26.7^{3} \pm 3.5$ & 0 & - & $371.53 * * *$ \\
\hline Lycopersicon & $1600 \pm 122$ & - & $46.7^{2,3}$ & \pm 5 & 5.6 & $13.3^{3} \pm 1.7$ & $26.7 \pm 2.0$ & - & $68.72 * * *$ \\
\hline Thiene & $2600 \pm 220$ & $33.0 \pm 4.0$ & 46.7 & \pm 4 & 4.3 & $20.0 \pm 6.0$ & 0 & 0 & $38.55 * *$ \\
\hline
\end{tabular}

-: no data

f.w.: fresh weight

$* * * \mathrm{P} \leq 0.001 ; * * \mathrm{P} \leq 0.01 ; * \mathrm{P} \leq 0.05$

Values represent the mean of 3 fruits $\pm \mathrm{S}$. E

1: NA; 2 : CA $0.5 \% \mathrm{CO}_{2}-2 \% \mathrm{O}$; 3 : $\mathrm{CA} 3 \% \mathrm{CO}_{2}-2 \% \mathrm{O}_{2}$; 4 : VACUUM $70 \mathrm{~mm} \mathrm{Hg}$

The figures above averages show that they are significantly different from the treatment(s) indicated by the figure

Table 3

Concentration of acetaldehyde in persimmon tissue ( $\mathrm{mg} / \mathrm{l} 00 \mathrm{~g} \mathrm{f} . \mathrm{w}$.) before and after storing the fruit under different storage conditions for 100 days

\begin{tabular}{|c|c|c|c|c|c|c|c|c|}
\hline \multirow{2}{*}{ Cultivar } & \multirow{2}{*}{ At harvest } & \multicolumn{6}{|c|}{ After storage } & \multirow{2}{*}{ F value } \\
\hline & & 1 & 2 & 2 & & 3 & 4 & \\
\hline Kaki Tipo & $0.03 \pm 0.01$ & $1.2^{3,4} \pm 0.15$ & $1.2^{3,4} \pm$ & \pm 0.17 & $1.7^{4}$ & \pm 0.17 & $0.6 \pm 0.06$ & $26.40^{* * *}$ \\
\hline Lycopersicon & $0.01 \pm 0.005$ & $1.3^{2,3} \pm 0.17$ & $1.0 \pm$ & \pm 0.08 & 0.8 & \pm 0.11 & - & $12.06^{* *}$ \\
\hline Thiene & $0.06 \pm 0.008$ & $0.8^{3} \pm 0.11$ & $0.7^{3} \pm$ & \pm 0.17 & $1.3^{4}$ & \pm 0.17 & $0.7 \pm 0.17$ & $9.42 * *$ \\
\hline
\end{tabular}

-: no data

Values represent the mean of 3 fruits \pm S.E.

$* * * \mathrm{P} \leq 0.001 ; * * \mathrm{P} \leq 0.01 ; * \mathrm{P} \leq 0.05$

1: NA; 2 : CA $0.5 \% \mathrm{CO}_{2}-2 \% \mathrm{O}_{2} ; 3$ : $\mathrm{CA} 3 \% \mathrm{CO}_{2}-2 \% \mathrm{O}_{2}$; 4: VACUUM $70 \mathrm{~mm} \mathrm{Hg}$

The figures above averages show that they are significantly different from the treatment(s) indicated by the figure

Ethanol concentration rises during the storage period, depending on the storage conditions (Table 4). The lowest ethanol content was found in fruit stored in NA, followed by $\mathrm{CA} 0.5 \% \mathrm{CO}_{2}-2 \% \mathrm{O}_{2}$ and $\mathrm{CA} 3 \% \mathrm{CO}_{2}-2 \% \mathrm{O}_{2}$. Additional $\mathrm{CO}_{2}$ provoked a higher ethanol concentration than did only the $\mathrm{CA} 0.5 \% \mathrm{CO}_{2}-2 \% \mathrm{O}_{2}$, which agrees with the observation of PESIS and BEN-ARIE (1984). Interestingly, the highest ethanol concentration was observed in fruit stored in a vacuum, probably because of a very low $\mathrm{O}_{2}$ concentration. PESIS and co-workers (1988) also demonstrated a higher ethanol 
accumulation in vacuum stored persimmon than in $\mathrm{CO}_{2}$ treated fruit. On the other hand, PESIS and BEN-ARIE (1984) reported an inhibition of ADH with high $\mathrm{CO}_{2}$ treatment and a consequently higher build-up of acetaldehyde.

\subsection{Activity of alcohol dehydrogenase}

$\mathrm{ADH}$ activity increased during the ripening of the control fruit or the $\mathrm{CO}_{2}$ treated fruit (Fig. 1). No clear differences between $\mathrm{ADH}$ activity in the control fruit and the $\mathrm{CO}_{2}$ treated fruit were observed. Increased ADH activity resulted in an ethanol accumulation, but there was no clear relationship between the ADH activity and ethanol accumulation.

Table 4

Concentration of ethanol in persimmon $(\mathrm{mg} / 100 \mathrm{~g} f$.w.) before and after storing the fruit under different storage conditions

\begin{tabular}{|c|c|c|c|c|c|c|c|c|c|c|}
\hline \multirow{2}{*}{ Cultivar } & & & \multicolumn{7}{|c|}{ After storage } & \multirow{2}{*}{ F value } \\
\hline & At harvest & & 1 & & 2 & & 3 & & 4 & \\
\hline Kaki Tipo & $3.7 \pm 0.06$ & $40.9^{2,3,4}$ & \pm 4.4 & $62.4^{4}$ & \pm 8.2 & $69.8^{4}$ & \pm 7.2 & 91.1 & \pm 7.4 & $38.09 * * *$ \\
\hline Lycopersicon & $4.1 \pm 0.17$ & $50.4^{2,3}$ & \pm 2.6 & $80.0^{3}$ & \pm 5.3 & 90.4 & \pm 5.5 & & - & $59.52 * * *$ \\
\hline Thiene & $3.3 \pm 0.30$ & $41.2^{3,4}$ & \pm 2.9 & $49.6^{4}$ & \pm 4.3 & $57.7^{4}$ & \pm 0.8 & 82.6 & \pm 6.8 & $43.70 * * *$ \\
\hline
\end{tabular}

-: no data

Values represent the mean of 3 fruits \pm S.E.

$* * * \mathrm{P} \leq 0.001 ; * * \mathrm{P} \leq 0.01 ; * \mathrm{P} \leq 0.05$

1:NA; 2 : CA $0.5 \% \mathrm{CO}_{2}-2 \% \mathrm{O}_{2} ; 3$ : $\mathrm{CA} 3 \% \mathrm{CO}_{2}-2 \% \mathrm{O}_{2} ; 4$ : VACUUM $70 \mathrm{~mm} \mathrm{Hg}$

The figures above averages show that they are significantly different from the treatment(s) indicated by the figure



Fig. 1. Activity of alcohol dehydrogenase (U) of Fuji persimmon treated with $\mathrm{CO}_{2}$ for $20 \mathrm{~h}(---\square---)$ and control fruit stored in air $(-\diamond-)$. Data represent means of 3 replicates \pm SE 


\title{
2.5. Astringency removal
}

The Lycopersicon and Thiene cultivars lost their astringent taste after $92 \mathrm{~h}$ during the astringency removal; tannin decreased to $20 \mathrm{mg} / 100 \mathrm{~g}$ (Table 5), the same level as during normal ripening (Table 2). The Kaki Tipo cultivar retained soluble tannins within $92 \mathrm{~h}$, so it did not loose its astringent taste. This cultivar needs a longer (48 h) $\mathrm{CO}_{2}$ exposure and additional storage at $20^{\circ} \mathrm{C}$ for $72 \mathrm{~h}$. A certain lag phase is required before the acetaldehyde builds up to a certain level and reacts with the tannins (GAZIT \& ADATO, 1972). Acetaldehyde is formed in an enzymatic system from pyruvate and accumulates in cytosol; soluble tannins are present in vacuoles. Thus, it is impossible for the acetaldehyde to react directly with tannins (MATsUO \& ITOO, 1977).

Table 5

The amount of soluble tannin in persimmon $(\mathrm{mg} / 100 \mathrm{gf.w}$.) before treatment and after astringency removal (92 $h$ from the beginning)

\begin{tabular}{lccc}
\hline Cultivar & Before treatment & After $92 \mathrm{~h}$ & F value \\
\hline Kaki Tipo & $2350 \pm 366$ & $2350 \pm 360$ & 0.00 \\
Lycopersicon & $2600 \pm 265$ & $20 \pm 2.6$ & $285.25^{* * *}$ \\
Thiene & $2600 \pm 300$ & $20 \pm 2.6$ & $221.86^{* * *}$ \\
\hline
\end{tabular}

Values represent the mean of 3 fruits.

$* * * \mathrm{P} \leq 0.001 ; * * \mathrm{P} \leq 0.01 ; * \mathrm{P} \leq 0.05$

\author{
Table 6
}

Concentration of acetaldehyde in persimmon $\left(\mathrm{mg} / 100 \mathrm{~g} f . w\right.$.) before treatment, after $20 \mathrm{~h}$ of $\mathrm{CO}_{2}$ treatment and after additional $72 \mathrm{~h}$ of storage at $20^{\circ} \mathrm{C}$

\begin{tabular}{lcccc}
\hline Cultivar & 1 & 2 & 3 & F value \\
\hline Kaki Tipo & $0.03^{2,3} \pm 0.005$ & $2.9 \pm 0.20$ & $2.6 \pm 0.20$ & $258.04 * * *$ \\
Lycopersicon & $0.01^{2,3} \pm 0.005$ & $1.4^{3} \pm 0.15$ & $2.3 \pm 0.20$ & $184.61 * * *$ \\
Thiene & $0.06^{2,3} \pm 0.01$ & $1.9 \pm 0.20$ & $1.7 \pm 0.30$ & $69.64 * * *$ \\
\hline
\end{tabular}

Values represent the mean of 3 fruits $\pm S$.E.

$* * * \mathrm{P} \leq 0.001 ; * * \mathrm{P} \leq 0.01 ; * \mathrm{P} \leq 0.05$

1: before treatment; 2 : after $20 \mathrm{~h}$ in $\mathrm{CO}_{2} ; 3$ : after $72 \mathrm{~h}$ in air (92 $\mathrm{h}$ from the beginning)

The figures above averages show that they are significantly different from the treatment(s) indicated by the figure 
Table 7

Concentration of ethanol in persimmon $\left(\mathrm{mg} / 100 \mathrm{~g} f . w\right.$.) before treatment, after $20 \mathrm{~h}$ of $\mathrm{CO}_{2}$ treatment and after additional $72 \mathrm{~h}$ of storage at $20^{\circ} \mathrm{C}$

\begin{tabular}{lcccc}
\hline Cultivar & 1 & 2 & 3 & F value \\
\hline Kaki Tipo & $3.7^{2,3} \pm 0.15$ & $27.0^{3} \pm 4.1$ & $46.0 \pm 5.0$ & $96.21^{* * *}$ \\
Lycopersicon & $4.1^{2,3} \pm 0.20$ & $15.4^{3} \pm 1.1$ & $70.3 \pm 6.0$ & $302.43^{* * *}$ \\
Thiene & $3.3^{2,3} \pm 0.40$ & $22.3^{3} \pm 0.7$ & $45.6 \pm 4.2$ & $218.00^{* * *}$ \\
\hline
\end{tabular}

Values represent the mean of 3 fruits \pm S.E.

$* * * \mathrm{P} \leq 0.001 ; * * \mathrm{P} \leq 0.01 ; * \mathrm{P} \leq 0.05$

1: before treatment; 2 : after $20 \mathrm{~h}$ in $\mathrm{CO}_{2} ; 3$ : after $72 \mathrm{~h}$ in air ( $92 \mathrm{~h}$ from the beginning)

Table 8

Sensory evaluation of Fuji cultivar carried out by 15 trained panellists. Ciphers represent the numbers of panellists who chose the given parameter

\begin{tabular}{lccccccc}
\hline & \multicolumn{5}{c}{ Compared to the reference ${ }^{\mathrm{a}}$ sample, } & $\mathrm{CO}_{2}$ treated fruit is & \multirow{2}{*}{ General } \\
\cline { 2 - 6 } & sweet & sour & firm & juicy & aromatic & astringent & impression \\
\hline much more & 1 & & 11 & 1 & 2 & & 6 \\
more & 4 & 1 & 4 & 2 & 2 & & 4 \\
slightly more & 4 & 5 & & 1 & 2 & 4 & 1 \\
equal & 1 & 5 & & 2 & 5 & 6 & 3 \\
slightly less & 4 & 4 & & 4 & 2 & 3 & 1 \\
less & 1 & & & 4 & 1 & 2 & \\
much less & & & & 1 & 1 & & \\
\hline
\end{tabular}

a: naturally ripened

Acetaldehyde becomes a substrate for alcohol dehydrogenase and is converted to ethanol, which builds in cytosol. Sodium bisulfite and dimedon, which are acetaldehydebinding agents, inhibit astringency removal (MATSUO \& ITOO, 1977). MATSUO and ITOO (1977) proposed a two stage deastringency process. In the first step, the fruit produces acetaldehyde via glycolysis. In the second step, acetaldehyde affects soluble tannins in the vacuoles and causes their polycondensation.

The acetaldehyde concentration rose within $20 \mathrm{~h}$ during the deastringency treatment, but did not change significantly afterwards with the exception of cultivar Lycopersicon (Table 6). Acetaldehyde accumulated during the anaerobic or high $\mathrm{CO}_{2}$ treatment only, then remained at the same level or with few changes. Acetaldehyde also accumulates in persimmons treated with warm water (MATSUO \& ITOO, 1977), or during chilling injuries when the temperature goes below $0{ }^{\circ} \mathrm{C}$. Both hot water treated or chilled fruits are known to be non astringent. The fruit responded to stress caused by 
chilling or high temperatures with an accumulation of acetaldehyde and the consequent polymerisation of tannins. More acetaldehyde accumulates during high $\mathrm{CO}_{2}$ treatment than during normal ripening. PESIS and BEN-ARIE (1984) demonstrated that $\mathrm{CO}_{2}$ and $\mathrm{N}_{2}$ affect the acetaldehyde accumulation differently; $\mathrm{CO}_{2}$ always produces more acetaldehyde, but may provoke internal browning when the fruit is exposed to high $\mathrm{CO}_{2}$ for too long.

The ethanol increased after $20 \mathrm{~h}$ of $\mathrm{CO}_{2}$ treatment, but its concentration increased significantly (nearly twofold) in the next $72 \mathrm{~h}$ (Table 7). Ethanol accumulation is the fruit tissue response to convert the toxic acetaldehyde into ethanol. More ethanol accumulated during normal ripening as compared to the high $\mathrm{CO}_{2}$ treatment. The acetaldehyde accumulation was much slower during natural ripening, compared to the high $\mathrm{CO}_{2}$ treatment; the higher acetaldehyde content caused tannin polymerisation in a much faster and efficient way. This agrees with the observation of PESIS and BEN-ARIE (1984) that $\mathrm{CO}_{2}$ inactivates $\mathrm{ADH}$, and thus prevents the conversion of acetaldehyde into ethanol.

\subsection{Sensorial properties}

The high $\mathrm{CO}_{2}$ treated fruits were rather firm at the edible stage and preferred by the panelists to the naturally ripened fruits (Table 8). The $\mathrm{CO}_{2}$ treated fruit were also considered less juicy compared to the control fruit. Such fruit can be stored at $0{ }^{\circ} \mathrm{C}$ to prolong their storage life with no risk of astringency reoccurring.

\section{Conclusion}

Natural ripening, storing or astringency removal by high $\mathrm{CO}_{2}$ treatment provoke an increase of acetaldehyde, ethanol and a decrease of soluble tannins. Astringency removal is usually brought to an end in $92 \mathrm{~h}$ by means of high $\mathrm{CO}_{2}$ treatment. The natural ripening takes much longer - about 30 days depending on the storage conditions to confer a non astringent taste. Some cultivars like Kaki Tipo may require longer $\mathrm{CO}_{2}$ exposure to remove astringency efficiently. Anaerobic metabolism provoked by high $\mathrm{CO}_{2}$ and/or low $\mathrm{O}_{2}$ enable the accumulation of acetaldehyde, a substance responsible for tannin insolubilisation. Fruit firmness, an important attribute to pome fruits quality, does not change during astringency removal, although some authors have found a partial fruit softening. On the other hand, naturally ripened persimmon is very soft at the edible stage, and thus susceptible to mechanical damage, and later on, to microbiological spoilage.

The authors are grateful to dr. L. GAŠPERLIN for her comments on statistical evaluation. 


\section{References}

BELliNI, E. (1982): Cultivar. -in: BALDINI, E. \& SCARAMUZZI, F. (Eds) Il Kaki, Reda, Roma, pp. 9-48.

BONGH, C., RAMINA, A., RUPERTI, B., VIDRIH, R. \& TONUTTI, P. (1999): Peach fruit ripening and quality in relation to picking time, and hypoxic and high $\mathrm{CO}_{2}$ short-term postharvest treatments. Postharvest Biol. Technol., 16, 213-222.

CHOI, J. U. (1977): On the changes of acetaldehyde, alcohol and tannin during the removal of astringency by carbon dioxide. J. Korean agric. Chem. Soc., 20, 1, 1-4.

CHOI, J. U. \& SOHN, T. H. (1977): Studies on the utilisation of persimmons (Part 4). On the changes of acetaldehyde, alcohol and tannin during the removal of astringency by carbon dioxide. J. Korean agric. Chem. Soc., 20, 1, 105-108.

GAZIT, S. \& ADATO, I. (1972): Effects of carbon dioxide atmosphere on the course of astringency disappearance of persimmon (Diospyros kaki L.) fruits. J. Fd Sci., 37, 815-817.

Hulme, A. C. (1971): The biochemistry of fruits and their products. Vol 2. Academic Press, London, pp. 281-301.

ITOO, S. (1971): The persimmon. -in: HulmE, A. C. (Ed.) The biochemistry of fruits and their products. Vol. 2. Academic Press, London, pp. 281-301.

KAYS, S. J. (1991): Postharvest physiology of perishable plant products. Van Nostrand Reinhold, New York, pp. 1-532.

KE, D. \& VAN GORSEL., H. (1990): Physiological and quality responses of 'Bartlett' pears to reduced $\mathrm{O}_{2}$ and enhanced $\mathrm{CO}_{2}$ levels and storage temperature. J. Am Soc. hortic. Sci., 115, 435-439.

MATSUO, T. \& ITOO, S. (1977): On mechanisms of removing astringency in persimmon fruits by carbon dioxide treatment I. Some properties of the two processes in the de-astringency. Plant Cell Physiol., $18,17-25$.

MATSUO, T. \& ITOO, S. (1978): The chemical structure of Kaki - tannin from immature fruit of the persimmon (Diospyros kaki, L.). Agric. biol Chem., 42, 9, 1637-1643.

MATSUO, T. \& ITOO, S. (1981a): Comparative studies of condensed tannins from several young fruits. $J$. Japanese Soc. Hortic. Sci., 50, 2, 262-269.

MATSUO, T. \& ITOO, S. (1981b): A simple and rapid purification method of condensed tannins from several young fruits. Agric. biol. Chem., 45, 8, 1885-1887.

MATSUO, T. \& ITOO, S. (1982): A model experiment for de-astringency of persimmon fruit with high carbon dioxide treatment: in vitro gelation of kaki-tannin by reacting with acetaldehyde. Agric. biol. Chem., $46,3,683-689$.

NAKAMURA, R. (1973): Studies on the mechanisms of the removal of astringency in Japanese persimmons (Diospyros kaki L.). Varietal difference of acetaldehyde contents, ethanol contents and alcohol dehydrogenase activities of kaki fruits J. Japanese Soc. Fd Sci. Technol., 20, 529-536.

PESIS, E. \& BEN-ARIE, R. (1984): Involvement of acetaldehyde and ethanol accumulation during induced deastringency of persimmon fruits. J. Fd Sci., 49, 896-899.

PESIS, E., LEVI, A., \& BEN-ARIE, R. (1988): Role of acetaldehyde production in the removal of astringency from persimmon fruits under various modified atmospheres. J. Fd Sci., 53, 153-156.

SAS (1990): SAS/STAS User's Guide. 4th ed., Cary, SAS Institute Inc., pp. 891-1230.

SEONG, J. H. (1986): The natural removal of astringency in sweet persimmon fruit and the distribution of tannin substance in leaf and fruit. M. Sc. Thesis. Kyungpook National University, Department of Agricultural Chemistry, Graduate School. Taegu, Korea, p. 45.

SMAGUlA, J. M. \& BRAMLAGE, W. J. (1977): Acetaldehyde accumulation: is it a cause of physiological deterioration of fruits? HortScience, 20, 200-203. 
SugiurA, A., YONEMORI, K., HARADA, H. \& TOMANA, T. (1979): Changes of ethanol and acetaldehyde contents in Japanese persimmon fruits and their relation to natural deastringency, Studies from Institute of Horticulture, Kyoto University, 9, 41-47.

SugiuRA, A. \& TOMANA, T. (1983): Relationship of ethanol production by seeds of different types of Japanese persimmons and their tannin content. HortScience, 18, 319-321.

VIDRIH, R., ZAVRTANIK, M. \& HRIBAR, J. (1998): Effect of low $\mathrm{O}_{2}$, high $\mathrm{CO}_{2}$ or added acetaldehyde and ethanol on postharvest physiology of cherries, Acta Horticulturae, 468, 695-703.

VIDRIH, R., ZAVRTANIK, M., \& HRIBAR, J. (1999): The influence of added acetaldehyde and ethanol on changes of aroma compounds in apples. Acta Horticulturae, 485, 383-388.

Wilkinson, B. G., \& FiDleR, J. C. (1973): Physiological disorders. -in: FIDLER, J. C., WilkinsON, B. G., EDNEY, K. L. \& SHARPLES, R. O. (Eds) The biology of apple and pear storage. Farnham Royal, Slough, SL2 3BN, UK, Commonwealth-Agricultural-Bureaux, pp. 63-131. 